\title{
Association Between Cytosolic Glycerol 3-Phosphate Dehydrogenase Gene Expression in Human Subcutaneous Adipose Tissue and BMI
}

\author{
Tomasz Sledzinskia Justyna Korczynska ${ }^{a}$ Elzbieta Goyke ${ }^{b} \quad$ Tomasz Stefaniak \\ Monika Proczko-Markuszewskac ${ }^{c}$ Lukasz Kaskac $^{c}$ Julian Swierczynski ${ }^{b}$ \\ aDepartment of Pharmaceutical Biochemistry, Medical University of Gdansk, Gdansk, Poland; \\ bDepartment of Biochemistry, Medical University of Gdansk, Gdansk, Poland; 'Department of General, \\ Endocrine and Transplant Surgery, Medical University of Gdansk, Gdansk, Poland
}

\section{Key Words}

Cytosolic glycerol 3-phosphate dehydrogenase -Triacylglycerol $P$ PAR $•$ Phosphoenolpyruvate carboxykinase • Leptin • Adiponectin • FAT/CD36 • Obesity

\begin{abstract}
Background/Aims: Cytosolic glycerol 3-phosphate dehydrogenase (cGPDH) is a key enzyme providing glycerol 3-phosphate for triacylglycerol synthesis in adipose tissue and is regarded as a marker for adipocyte differentiation. The aim of this study was to test the hypothesis that an increase in CGPDH gene expression in subcutaneous adipose tissue is associated with obesity. Methods: mRNA levels in human subcutaneous adipose tissue were analysed by Real-Time PCR. Results: We found that human subcutaneous adipose tissue cGPDH activity and CGPDH mRNA level were greater in obese patients than in lean subjects and were positively correlated with BMI and fat mass. Moreover, a strong positive correlation between subcutaneous adipose tissue cGPDH mRNA level and cGPDH activity was found. The data presented here indicates also that PPARY mRNA level is positively correlated with body mass index and fat mass as well as with adipose tissue cGPDH mRNA level. Moreover, the association between subcutaneous adipose tissue cGPDH mRNA level and fatty acid translocase (FAT/CD36) mRNA level was also observed. Conclusion: The obtained results suggest that in comparison to lean subjects the increase in subcutaneous adipose tissue cGPDH gene expression in the obese, is probably the result of adipose tissue expansion during obesity.
\end{abstract}




\section{Introduction}

Obesity, a global health problem, constitutes a heterogeneous disorder caused by the interaction between genetic, environmental, and psychosocial factors [1]. It is associated with numerous diseases, including type 2 diabetes mellitus and coronary heart disease [1, 2]. Generally, it is believed that the imbalance between food intake and caloric expenditure, leading to the excessive accumulation of triacylglycerols (TAG) in adipose tissue, may play a key role in developing obesity. It seems, therefore, that an excessive level of substrates required for TAG synthesis could play an important role in the development of human obesity. Fatty acids (namely, long chain acyl-CoA) and glycerol 3-phosphate (G3P) serve as the direct precursors for TAG synthesis in adipose tissue. In fed state, fatty acids necessary for TAG synthesis in human adipose tissue can arise from lipoproteins (mainly from chylomicrons and VLDL) [3] and/or can be synthesized in adipocytes [4]. In human adipose tissue, G3P can arise from: a) glucose, namely from dihydroxyacetone phosphate (DHAP) - a glycolytic metabolite, b) lactate, pyruvate, and some amino acids through glyceroneogenesis pathway, where PEP-CK plays a key role [5], and c) from glycerol via glycerol phosphorylation catalysed by glycerol kinase. Since glycerol kinase activity is very low in human adipose tissue [6], it is unlikely that G3P is formed directly from glycerol. Thus, G3P in human adipose tissue can arise from glucose (mainly in fed state) and/or through glyceroneogenesis pathway (in fasted state). DHAP, formed in glycolysis or glyceroneogenesis, is converted to G3P by cGPDH. In an earlier paper, we have shown that cGPDH activity is elevated in human subcutaneous adipose tissue of obese subjects [7]. Both in vivo and in vitro studies indicate that cGPDH activity is proportional to mRNA level $[8,9]$. However, we have not examined this issue previously [7].

Peroxisome proliferator activated receptor $\gamma$ (PPAR $\gamma$ ), highly expressed in human adipose tissue [10], is the master regulator of lipid storage in adipose tissue and adipocyte differentiation [11-13]. Moreover, it has been shown that cGPDH gene is a PPAR $\gamma$ target gene in adipose tissue [14]. The association between PPAR $\gamma$ gene expression in human adipose tissue and body mass index (BMI) has been observed, however, the published data is inconsistent. Some data indicates that PPAR $\gamma$ mRNA in subcutaneous adipose tissue of obese patients is significantly higher than in non-obese subjects, while PPAR $\gamma$ mRNA in retroperitoneal adipose tissue of obese subjects is decreased as compared to non-obese subjects [15]. Macias-Gonzales et al. [16] reported that the PPAR $\gamma$ mRNA level in subcutaneous adipose tissue is significantly higher in morbidly obese patients with insulin resistance as compared to morbidly obese patients without insulin resistance. Recently published data indicates no difference in PPAR $\gamma$ gene expression both in human subcutaneous and visceral adipose tissue between non-obese and obese subjects [17]. Leyvraz et al. [18] showed that PPAR 1 and 2 are differently regulated in obesity, only PPAR $\gamma 1$ was found to be decreased in obese women. Despite these discordances, we hypothesized that PPAR $\gamma$, which is responsible for lipid storage in adipose tissue, adipocyte differentiation and regulation of cGPDH gene expression [14], would be up-regulated in subcutaneous adipose tissue of obese subjects.

The aim of this study was to examine whether an increase in the expression of cGPDH and PEP-CK genes (encoding enzymes providing G3P for TAG synthesis) are associated with BMI (and fat mass) and with PPAR $\gamma$ mRNA level. For comparative purposes, we also measured the levels of FAT/CD36, leptin and adiponectin mRNA levels in the same sample of adipose tissue.

\section{Materials and Methods}

\section{Patients}

Eighteen non-diabetic, obese patients ( 3 males and 15 females with $\mathrm{BMI}=46 \pm 1.6 \mathrm{~kg} / \mathrm{m}^{2}$, range: 38 64) aged between 22 and 55 years (mean age: $42 \pm 1.9$ years) underwent a Roux-en-Y gastric bypass (RYGB) at the Department of General, Endocrine, and Transplant Surgery (Medical University of Gdansk, Poland). 
All the obese patients were on low-calorie diet (800-1000 kcal/day, with high proteins and low fat and carbohydrates) for 3 months prior to the surgery. The lean group consisted of 14 subjects ( 3 males and 11 females with BMI $=25 \pm 1 \mathrm{~kg} / \mathrm{m}^{2}$, range: 18-29) aged between 18 and 63 years (mean age: $47 \pm 3.5$ years) who underwent cholecystectomy or hernia operation at the Department of General, Endocrine, and Transplant Surgery (Medical University of Gdansk, Poland). After an overnight fast, blood specimens were obtained for assays. During the surgery, pieces of subcutaneous adipose tissue, weighing approximately $1 \mathrm{~g}$ each, were removed and immediately frozen in liquid nitrogen. The investigations were consistent with the Declaration of Helsinki of the World Medical Association and were approved by the Medical University of Gdansk Ethics Committee. All patients participating in the study signed an informed consent form for the investigation. Serum insulin and glucose concentrations were assayed by Central Clinical Laboratory of the Medical University of Gdansk. Adipose tissue mass of obese patients was measured by Tanita SC 330S Body composition Analyser.

mRNA level analysis

The total cellular RNA was extracted from frozen adipose tissue with the Qiagen RNeasy Lipid Tissue Midi Kit. The quantity and quality of the resulting RNA was assessed by automated gel electrophoresis (Experion, Bio-Rad Laboratories). The cDNA was synthesized from $0.5 \mu \mathrm{g}$ of total RNA using the Biorad iSCRIPT cDNA Synthesis Kit. Each RNA sample was treated with RNase-free DNase I before cDNA synthesis. The mRNA levels were analysed with real-time PCR with the iCycler iQ Real Time Detection System (Bio-Rad). The reaction was performed using the iQ SYBR Green Supermix (Bio-Rad). The combination of $\beta$-actin and cyclophilin genes was used as the standard. The relative mRNA levels of the studied genes were calculated by the method presented by Piehler et al. [19]. The primers sequences were: F: 5'TGTCACCAACTGGGACGATA, R: 5'GGGGTGTTGAAGGTCTCAAA for $\beta$-actin; F: 5' TCGAGTTGTCCACAGTCA, R: 5'CGTCTCCTTTGAGCTGT for cyclophilin, F: 5'GAGGTGGCTGATGAGAAG, R: 5'CTGTGATACGGAAGTTTGG for cGPDH, F: 5'AGGCCATTTTCTCAAAC,R:5'AGAAATGCTGGAGAAGTCAACAforPPAR $\gamma 1$-3;F:5'CGGAACCATCTTGGCAACA,R: 5'GCCGGTTGATAGGCAGCTT forSREBP1;F:5'GACAAGCACAGCGACGAGTA, R: 5'AGCTGCTCCACCTTCTTCTGfor C/EBPB $\beta$; F: 5'-GCTCTGAGGAGGAGAATGG-3', R: 5'-TGCTCTTGGGTGACGATAAC-3' for phosphoenolpyruvate carboxykinase (PEPCK), F: 5'-AAGTCACTGCGACATGAT TAATGG-3', R: 5'-GAACTGCAATACCTGGCTTTTCTC-3' for FAT/CD36, F 5'GGAATGAAGTCCAAACCGGTG,R: 5'GTGCGGATTCTTGTGGCTTT for leptin, and F: 5'-TGGTGAGAAGGGTGAGAA-3', R: 5'-AGATCTTGGTAAAGCGAATG-3' for adiponectin. The amplification of specific transcripts was confirmed by obtaining the melting curve profiles and agarose gel electrophoresis of the amplification products.

\section{cGPDH activity assay}

Approximately $0.5 \mathrm{~g}$ of adipose tissue was rinsed, blotted dry, and placed in $5 \mathrm{ml}$ ice-cold $20 \mathrm{mM}$ Tris hydrochloride buffer $(\mathrm{pH} 7.8)$ containing $0.2 \%$ Triton X-100. The tissue was finely minced with scissors, homogenized manually with a Teflon pestle homogenizer, and centrifuged at $30000 \times \mathrm{g}$ for $20 \mathrm{~min}$. After removing the fat cake, the resulting supernatant was decanted, and the pellet was resuspended in $5 \mathrm{ml}$ of the isolation medium, rehomogenized, and centrifuged as before. The supernatant was combined with that obtained after the first centrifugation step and used for enzyme assay. The activity of cGPDH (EC 1.1.1.8) was measured as described previously [7]. All assays were performed in duplicate at $37^{\circ} \mathrm{C}$ using a Beckman DU 68 spectrophotometer (Beckman Instruments, Fullerton, CA, USA). The absorbance changes both against time and against enzyme concentration were linear. Protein concentration assays were performed according to the method of Peterson.

Statistics

Statistical analyses were performed with SigmaStat. The statistical significance of the differences between obese and non-obese patients was assessed by the Student's t-test. Pearson's correlation coefficient was calculated to assess the correlation between the selected parameters in obese patients.

\section{Results}

The anthropometric and biochemical characteristics of lean and obese subjects included in the study are presented in Table 1 . All obese subjects had BMI above 
Table 1. Characteristics of non-obese subjects and obese patients included in the study. ${ }^{*} \mathrm{p}<0.01$

\begin{tabular}{lcc}
\hline parameter & $\begin{array}{c}\text { Nonobese subjects } \\
\text { Mean } \pm \text { SEM }\end{array}$ & $\begin{array}{c}\text { Obese patients } \\
\text { Mean } \pm \text { SEM }\end{array}$ \\
\hline Sex (female/male) & $11 / 3$ & $15 / 3$ \\
Age (years) & $47 \pm 3.5$ & $42 \pm 1.9$ \\
Body weight $(\mathrm{kg})$ & $66 \pm 3.3$ & $125 \pm 5.7^{*}$ \\
Adipose tissue mass $(\mathrm{kg})$ & $16 \pm 0.7$ & $57 \pm 3.3^{*}$ \\
BMI $\left(\mathrm{kg} / \mathrm{m}^{2}\right)$ & $25 \pm 1.0$ & $46 \pm 1.6^{*}$ \\
Serum glucose $(\mathrm{mg} / \mathrm{dL})$ & $89 \pm 3.7$ & $112 \pm 5.4^{*}$ \\
Serum insulin $(\mu \mathrm{U} / \mathrm{ml})$ & $5.1 \pm 0.66$ & $4.5 \pm 0.75$ \\
\hline
\end{tabular}

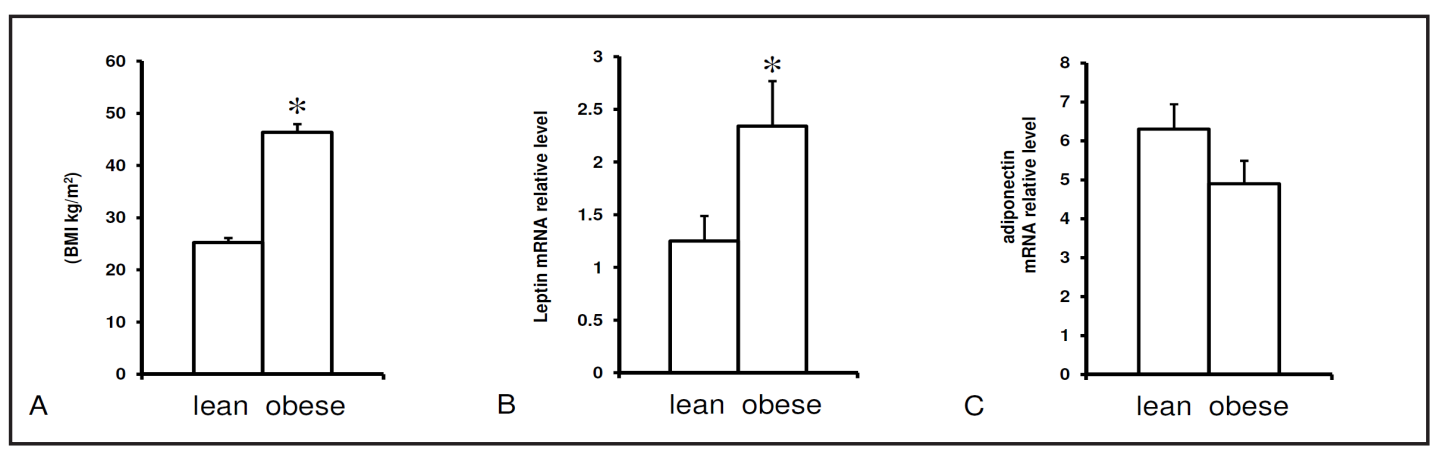

Fig. 1. The mean BMI (A), subcutaneous adipose tissue leptin (B), and adiponectin (C) relative mRNA levels in lean subjects and obese patients. Data are presented as mean \pm SEM, $* \mathrm{p}<0.05$.

Fig. 2. The mean cGPDH activity (A), and cGPDH relative mRNA level (B) in the subcutaneous adipose tissue in lean subjects and obese patients. Data are presented as mean $\pm \mathrm{SEM},{ }^{*} \mathrm{p}<0.05$.

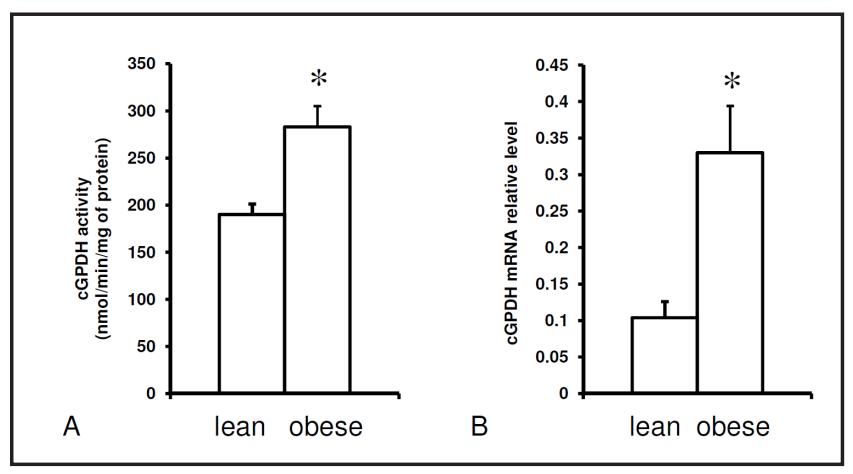

$35 \mathrm{~kg} / \mathrm{m}^{2}$. The mean BMI as well as mean body weight of obese subjects were approximately 2 -fold higher, while the mean fat mass was 3.5 times greater than in the lean subjects. Fasting serum glucose concentration was slightly higher in obese subject, however, insulin concentration was within normal range, and similar in lean and obese subjects. The mean age (and range of age) was similar in both groups. Since previous study on cGPDH activity showed no differences among sexes [7], the results are presented as single group, not divided by sex, although men are identified in some figures. The mean BMI and leptin mRNA level in subcutaneous adipose tissue of obese patients participating in the study were greater than in lean subjects (Fig. 1A and 1B), whereas adiponectin mRNA level in subcutaneous adipose tissue of obese subject was slightly lower than in lean subjects (Fig. 1C). As expected, based on the previously published data [7], subcutaneous adipose tissue cGPDH activity was 


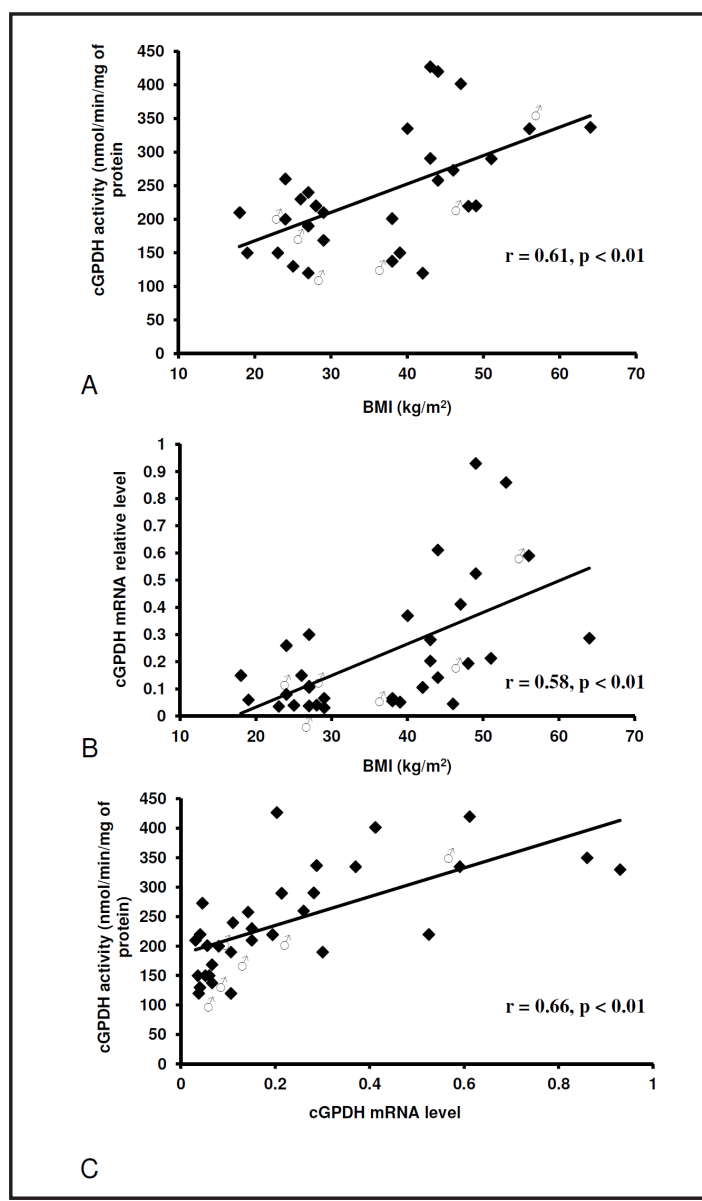

Fig. 3. The correlation between: cGPDH activity in the subcutaneous adipose tissue and the BMI (A); cGPDH relative mRNA level in the subcutaneous adipose tissue and the BMI (B); cGPDH activity and cGPDH relative mRNA level in the subcutaneous adipose tissue (C). Male subjects are labeled as $\hat{\sigma}$.

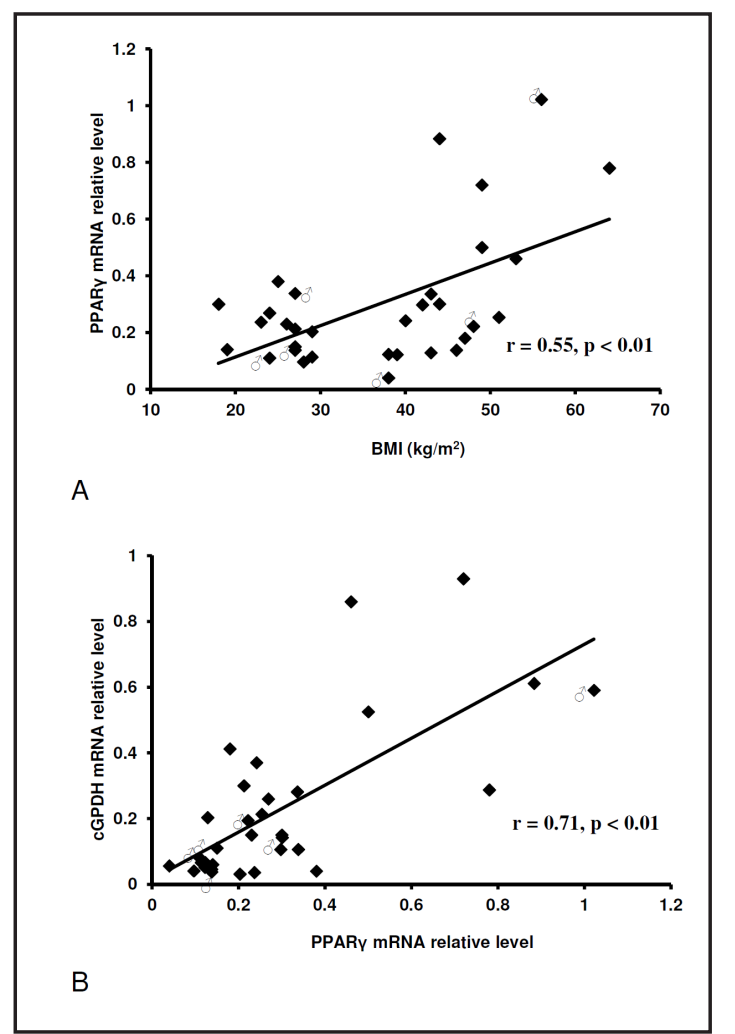

Fig. 4. The correlation between: PPAR $\gamma$ relative mRNA level in the subcutaneous adipose tissue and the BMI (A); cGPDH relative mRNA level and the PPAR $\gamma$ relative mRNA in the subcutaneous adipose tissue (B). Male subjects are labeled as $\hat{\sigma}$.

significantly higher in obese patients as compared to lean subjects (Fig. 2A). The cGPDH mRNA level in subcutaneous adipose tissue from obese patients was also significantly greater than in lean participants (Fig. 2B). Regression analysis of the data presented in Figs. 1 and 2, yielded a positive correlation between cGPDH activity and BMI $(\mathrm{r}=0.61 ; \mathrm{p}<0.01)$ (Fig. 3A) and positive correlation between cGPDH mRNA level and BMI $(\mathrm{r}=0.58 ; \mathrm{p}<0.01)$ (Fig. 3B). Essentially similar correlation between cGPDH activity or mRNA level and adipose tissue mass was found ( $\mathrm{r}=0.50, \mathrm{p}<0.01 ; \mathrm{r}=0.53, \mathrm{p}<0.01$, respectively). To prove that cGPDH activity in subcutaneous adipose tissue reflected cGPDH mRNA level, we analysed the correlation between the above mentioned parameters. As indicated in Fig. 3C, we found a strong positive correlation between cGPDH mRNA level and cGPDH activity $(r=0.66, p<$ 0.01 ). Moreover, we analysed the relationship between cGPDH gene expression and serum glucose or insulin concentrations. We did not find significant correlation between cGPDH mRNA level (and enzyme activity) and serum glucose or insulin concentrations (data not shown).

Data presented in Fig. 4A indicate that PPAR $\gamma$ mRNA level is positively correlated with BMI $(r=0.55, p<0.01)$. Essentially similar positive correlation between PPAR $\gamma$ mRNA level and body fat mass $(\mathrm{r}=0.63, \mathrm{p}<0.01)$, as well as between PPAR $\gamma$ mRNA level and body mass $(r=0.58, p<0.01)$, was also found. Strong positive correlation between PPAR $\gamma$ mRNA 
Table 2. Correlations between BMI, adipose tissue cGPDH, and PPAR $\gamma$ mRNA levels and selected genes expression in human subcutaneous adipose tissue. ${ }^{*} \mathrm{p}<0.01$, ${ }^{*} \mathrm{p}<0.05$

\begin{tabular}{lccc}
\hline & BMI & cGPDH mRNA level & PPAR $\gamma$ mRNA level \\
\hline $\begin{array}{l}\text { PEPCK mRNA level } \\
\text { (r - correlation coefficient) }\end{array}$ & 0.30 & 0.17 & $0.56^{*}$ \\
$\begin{array}{l}\text { FAT/CD36 mRNA level } \\
\text { (r - correlation coefficient) }\end{array}$ & $0.47^{*}$ & $0.54^{*}$ & $0.39^{\#}$ \\
$\begin{array}{l}\text { C } / \text { EBP } \beta \text { mRNA level } \\
(\mathrm{r}-\text { correlation coefficient) }\end{array}$ & 0.18 & 0.33 & 0.01 \\
$\begin{array}{l}\text { SREBP1 mRNA level } \\
(\mathrm{r}-\text { correlation coefficient) }\end{array}$ & -0.27 & -0.23 & -0.20 \\
\hline
\end{tabular}

level and cGPDH mRNA level in human subcutaneous adipose tissue $(r=0.71, p<0.01)$ (Fig. 4B) suggests that up-regulation of PPAR $\gamma$ gene expression in obese subjects could play a role in up-regulation of cGPDH gene expression. Since C/EBP $\beta$ plays an important role in activating PPAR $\gamma$ gene expression during early stage of adipocyte differentiation and SREBP1 potentiates the transcriptional activity of PPAR $\gamma$ [20], we analysed the association between cGPDH mRNA level (and enzyme activity) and these lipogenic factors. We have found a weak positive correlation between cGPDH mRNA level (and enzyme activity) and C/EBP $\beta$ mRNA level, however, the correlation did not reach statistical significance (Table 2). Surprisingly, no correlation between cGPDH mRNA and PPAR $\gamma$ was found (Table 2). Weak negative correlation (statistically insignificant) between cGPDH mRNA level and SREBP1 mRNA level was also observed (Table 2). Moreover, SREBP1 mRNA level displayed a decreasing trend in relation to obesity (Table 2).

Since PEP-CK gene in adipose tissue is induced by PPAR $\gamma$ [21], and a positive correlation between PEP-CK and PPAR $\gamma$ mRNA levels in human subcutaneous adipose tissue was found [22], we examined the relationship between PEP-CK mRNA level and BMI and between PEPCK mRNA level and PPAR $\gamma$ mRNA in subcutaneous adipose tissue of our patients for comparative purposes. We found a weak positive correlation between PEPCK mRNA level and BMI $(r=0.3)$ and a significant correlation between PEPCK mRNA level and PPAR $\gamma$ mRNA $(\mathrm{r}=0.50 ; \mathrm{p}<0.01)$ (Table 2). We found also a correlation between BMI and FAT/CD36 mRNA level (Table 2) and between cGPDH mRNA and FAT/CD36 mRNA levels (Table 2).

\section{Discussion}

In the present work, we have confirmed the previous report indicating that human subcutaneous adipose tissue cGPDH activity is positively correlated with BMI and body and fat mass [7]. Moreover, we have shown for the first time an increase in cGPDH mRNA level in obese patients. In contrast, previous studies suggested that cGPDH activity [23, 24] and cGPDH mRNA level [25] were slightly lower in subcutaneous adipose tissue of obese subjects as compared to the control. Variability in cGPDH activity, which exists in human adipose tissue, and a small number of patients included in the previously performed study, may constitute the possible explanation for the discrepancy between the results presented here and those reported several years ago [23-25].

In view of the fact that cGPDH is up-regulated by PPAR $\gamma$ in adipose tissue [14] and taking into consideration data presented in this paper, which indicates a strong association between cGPDH mRNA level and PPAR $\gamma$ mRNA level (Fig. 4B), it can be assumed that the activation of cGPDH gene expression results from PPAR $\gamma$ action in human subcutaneous adipose tissue. This corroborates well with previously reported observation that human subcutaneous preadipocytes displayed coordinated high lipid accumulation and up-regulation of cGPDH and PPAR $\gamma$ genes expression [26]. Contrary to what would be expected, the results presented 
here suggest a weak positive correlation between cGPDH mRNA level (and enzyme activity) and C/EBP $\beta$ mRNA level, however, the correlation did not reach statistical significance (Table 2). Moreover, no association between C/EBP $\beta$ and PPAR $\gamma$ mRNA level was found (Table 2). It is likely that in adipose tissue of obese subject factors other than C/EBP $\beta$ are required to regulate PPAR $\gamma$ gene expression and consequently cGPDH gene expression. Another possibility is that regulatory cascade controlling adipogenesis in obese subjects is disrupted by adipocytokine produced by adipose tissue. It is known that TNF $\alpha$, which is over-expressed in human adipose tissue of obese subjects [27], produced a marked decrease in SREBP1 mRNA level in isolated human adipocytes [28]. The weak negative correlation (statistically insignificant) between: a) BMI and SERBP1 mRNA level; b) cGPDH mRNA level and SREBP1 mRNA level; c) PPAR $\gamma$ and SREBP-1 genes expression (Table 2) seems to support the suggestion that transcription network involved in the regulation of PPAR $\gamma$, SREBP1, and $\mathrm{C} / \mathrm{EBP} \beta$ genes expression is dysregulated in adipose tissue of obese subjects.

Insulin increases the cGPDH gene expression in isolated human adipocytes [29]. Our results showed that serum insulin concentration in lean and obese subjects is similar. Thus, it is unlikely that insulin is responsible for elevated cGPDH gene expression in adipose tissue of obese subjects. No correlation between serum glucose concentration and adipose tissue cGPDH gene expression was found despite slightly higher serum glucose concentration in obese subjects. Thus, similarly to serum insulin, serum glucose concentration appears not to be an important factor regulating cGPDH expression in human subcutaneous adipose tissue.

Similarly to our previous study [7], we have found no relationship between cGPDH expression in adipose tissue and age and gender, however, the latter should be regarded with caution as only 3 lean and 3 obese males were included in this study.

Coordinated up-regulation of PPAR $\gamma$ and cGPDH genes expression during adipocyte differentiation and adipogenesis was also recently reported [30]. Current data indicates that resveratrol [31] or kefir [32] coordinately decrease lipid accumulation, cGPDH activity, and PPAR $\gamma$ gene expression in 3T3-L1 adipocytes. Furthermore, thiazolidinediones, recognized ligands for PPAR $\gamma$, promotes TAG storage in subcutaneous adipose tissue [33]. These in vivo and in vitro observations suggest that there is a strong association between TAG accumulation and $\mathrm{cGPDH}$ and PPAR $\gamma$ genes expression or PPAR $\gamma$ activation in adipose tissue. Moreover, it has been reported that the expression of PEP-CK gene can be stimulated by PPAR $\gamma$ via PPAR $\gamma$ response element present in promoter region of PEP-CK gene in adipose tissue [21, 34]. A positive correlation between PEPCK mRNA level in human subcutaneous adipose tissue and BMI was also reported [22]. Thus, one would expect that PPAR $\gamma$ coordinately upregulates cGPDH and PEPCK genes expression. Data presented in this paper indicates that this is the case. Both cGPDH and PEP-CK mRNA levels are positively correlated with PPAR $\gamma$ gene expression. Interestingly, cGPDH mRNA level correlated with the level of FAT/CD36 mRNA (Table 2) assayed in the same sample of adipose tissue. This suggests that common regulatory mechanism(s) might exist for cGPDH, PPAR $\gamma$, and FAT/CD36 genes expression in human adipose tissue and that this regulation is associated with obesity. Based on the data presented here, we propose that the over-expression of cGPDH gene in adipose tissue is a result of adipose tissue expansion during obesity development. Excessive accumulation of TAG in adipose tissue during development of obesity requires G3P production. As already mentioned, cGPDH activity is the main provider of G3P for TAG synthesis in adipose tissue. In fed state, fatty acids (namely acyl-CoA), constituting the direct precursors for TAG synthesis, can arise from lipoproteins [3]. Fatty acid translocase (FAT/CD36) facilitates FFA transport across the adipocyte membrane [35-39]. Increased membrane content of FAT/CD36 is associated with increased rate of LCFA transport [35-37]. Interestingly, up-regulation of FAT/ CD36 in adipose tissue of obese subjects has also been observed [40]. Thus, it is tempting to speculate that coordinated up-regulation of cGPDH and FAT/CD36 genes expression is involved in excessive TAG accumulation in adipose tissue during development of obesity. However, this proposal is discordant with the results indicating that the overexpression of cGPDH gene in subcutaneous adipose tissue in transgenic mice leads to a reduction in fat mass [41]. One possible explanation for the discrepancy is that abnormal overexpression of 
cGPDH gene (50-200-fold) leads to the activation of catabolic processes (for instance G3P cycle), which may result in the decrease of intracellular G3P concentration and consequently in a decrease of fat mass. On the other hand, loss of cGPDH in adipose tissue should lead to loss of fat mass. However, mice carrying the null allele for cGPDH are not deficient in their body fat mass [42]. Plausible explanations for these seemingly discrepant findings include the suspicion that mice synthesize TAG by acylation of DHAP by dihydroxyacetone phosphate acyltransferase as an alternative pathway of TAG synthesis in adipose tissue [42].

A number of limitations are present in this study. Firstly, the number of patients included in our study was relatively low. Secondly, applying our findings to the whole population of obese subjects should be approached with caution as these observations were made in nondiabetic, obese subjects, who were subjected to low-calorie diet with high proteins and low fat and carbohydrates for 3 months prior to the surgery. However, as far as cGPDH activity is concerned, the results presented here are essentially similar to those reported previously, which were performed on 60 obese subjects consuming a conventional diet [7]. Furthermore, very consistent correlation between cGPDH activity or cGPDH mRNA level and BMI supports the validity and relevance of findings presented in this paper.

In conclusion, our data suggests that cGPDH gene expression is elevated possibly as a result of adipose tissue expansion during development of obesity in humans. Coordinated over-expression of cGPDH, PEP-CK, and PPAR $\gamma$ genes together with up-regulation of fatty acids transporter in adipose tissue of obese subjects provide links between excessive energy intake and accumulation of TAG in adipocytes of obese subjects.

\section{Acknowledgements}

This work was supported by Medical University of Gdansk (Grants ST-40, ST-41, and ST -89).

\section{References}

1 Swierczynski J, Sledzinski T: The Role of Adipokines and Gastrointestinal Tract Hormones in Obesity; in Karcz WK, Thomusch O (eds): Principles of metabolic surgery, Springer Berlin Heidelberg, 2012, pp 53-79.

2 Kopelman PG: Obesity as a medical problem. Nature 2000;404:635-643.

-3 Gonzales AM, Orlando RA: Role of adipocyte-derived lipoprotein lipase in adipocyte hypertrophy. Nutr Metab (Lond) 2007;4:22.

-4 Swierczynski J, Goyke E, Wach L, Pankiewicz A, Kochan Z, Adamonis W, Sledzinski Z, Aleksandrowicz Z: Comparative study of the lipogenic potential of human and rat adipose tissue. Metabolism 2000;49:594599.

5 Reshef L, Hanson RW, Ballard FJ: Glyceride-glycerol synthesis from pyruvate. Adaptive changes in phosphoenolpyruvate carboxykinase and pyruvate carboxylase in adipose tissue and liver. J Biol Chem 1969;244:1994-2001. Ryall RL, Goldrick RB: Glycerokinase in human adipose tissue. Lipids 1977;12:272-277.

Swierczynski J, Zabrocka L, Goyke E, Raczynska S, Adamonis W, Sledzinski Z: Enhanced glycerol 3-phosphate dehydrogenase activity in adipose tissue of obese humans. Mol Cell Biochem 2003;254:55-59.

-8 Ratner PL, Fisher M, Burkart D, Cook JR, Kozak LP: The role of mRNA levels and cellular localization in controlling sn-glycerol-3-phosphate dehydrogenase expression in tissues of the mouse. J Biol Chem 1981;256:3576-3579.

-9 Kozak LP: Interacting genes control glycerol-3-phosphate dehydrogenase expression in developing cerebellum of the mouse. Genetics 1985;110:123-143.

10 Giusti V, Verdumo C, Suter M, Gaillard RC, Burckhardt P, Pralong F: Expression of peroxisome proliferatoractivated receptor-gamma1 and peroxisome proliferator-activated receptor-gamma2 in visceral and subcutaneous adipose tissue of obese women. Diabetes 2003;52:1673-1676. 
11 Rosen ED, Spiegelman BM: Molecular regulation of adipogenesis. Annu Rev Cell Dev Biol 2000;16:145-171.

12 Feige JN, Auwerx J: Transcriptional coregulators in the control of energy homeostasis. Trends Cell Biol 2007;17:292-301.

13 Lehrke M, Lazar MA: The many faces of PPARgamma. Cell 2005;123:993-999.

14 Patsouris D, Mandard S, Voshol PJ, Escher P, Tan NS, Havekes LM, Koenig W, März W, Tafuri S, Wahli W, Müller M, Kersten S: PPARalpha governs glycerol metabolism. J Clin Invest 2004;114:94-103.

15 Bortolotto JW, Margis R, Ferreira AC, Padoin AV, Mottin CC, Guaragna RM: Adipose tissue distribution and quantification of PPARbeta/delta and PPARgamma1-3 mRNAs: discordant gene expression in subcutaneous, retroperitoneal and visceral adipose tissue of morbidly obese patients. Obes Surg 2007;17:934-940.

-16 Macias-Gonzalez M, Moreno-Santos I, Garcia-Almeida JM, Tinahones FJ, Garcia-Fuentes E: PPARgamma2 protects against obesity by means of a mechanism that mediates insulin resistance. Eur J Clin Invest 2009;39:972-979.

17 Hammes TO, Costa CS, Rohden F, Margis R, de Almeida JC, Padoin AV, Mottin CC, Guaragna RM: Parallel down-regulation of FOX01, PPARgamma and adiponectin mRNA expression in visceral adipose tissue of class III obese individuals. Obes Facts 2012;5:452-459.

18 Leyvraz C, Verdumo C, Suter M, Paroz A, Calmes JM, Marques-Vidal PM, Giusti V: Changes in gene expression profile in human subcutaneous adipose tissue during significant weight loss. Obes Facts 2012;5:440-451.

19 Piehler AP, Grimholt RM, Ovstebo R, Berg JP: Gene expression results in lipopolysaccharide-stimulated monocytes depend significantly on the choice of reference genes. BMC Immunol 2010;11:21.

-20 Wu Z, Rosen ED, Brun R, Hauser S, Adelmant G, Troy AE, McKeon C, Darlington GJ, Spiegelman BM: Crossregulation of $\mathrm{C} / \mathrm{EBP}$ alpha and PPAR gamma controls the transcriptional pathway of adipogenesis and insulin sensitivity. Mol Cell 1999;3:151-158.

21 Glorian M, Duplus E, Beale EG, Scott DK, Granner DK, Forest C: A single element in the phosphoenolpyruvate carboxykinase gene mediates thiazolidinedione action specifically in adipocytes. Biochimie 2001;83:933-943.

$\checkmark 22$ Chang TJ, Lee WJ, Chang HM, Lee KC, Chuang LM: Expression of subcutaneous adipose tissue phosphoenolpyruvate carboxykinase correlates with body mass index in nondiabetic women. Metabolism 2008;57:367-372.

23 Alton DJ, Bray GA: Metabolism of alpha-glycerol phosphate in human adipose tissue in obesity. J Clin Endocrinol Metab 1967;27:1573-1580.

24 Galton DJ: An enzymatic defect in a group of obese patients. Br Med J 1966;2:1498-1500.

-25 Poulain-Godefroy O, Lecoeur C, Pattou F, Fruhbeck G, Froguel P: Inflammation is associated with a decrease of lipogenic factors in omental fat in women. Am J Physiol Regul Integr Comp Physiol 2008;295:R1-R7.

-26 Tchkonia T, Giorgadze N, Pirtskhalava T, Tchoukalova Y, Karagiannides I, Forse RA, DePonte M, Stevenson M, Guo W, Han J, Waloga G, Lash TL, Jensen MD, Kirkland JL: Fat depot origin affects adipogenesis in primary cultured and cloned human preadipocytes. Am J Physiol Regul Integr Comp Physiol 2002;282:R1286-R1296.

27 Hotamisligil GS, Arner P, Caro JF, Atkinson RL, Spiegelman BM: Increased adipose tissue expression of tumor necrosis factor-alpha in human obesity and insulin resistance. J Clin Invest 1995;95:2409-2415.

28 Sewter C, Berger D, Considine RV, Medina G, Rochford J, Ciaraldi T, Henry R, Dohm L, Flier JS, O'Rahilly S, Vidal-Puig AJ: Human obesity and type 2 diabetes are associated with alterations in SREBP1 isoform expression that are reproduced ex vivo by tumor necrosis factor-alpha. Diabetes 2002;51:1035-1041.

29 Moustaid N, Jones BH, Taylor JW: Insulin increases lipogenic enzyme activity in human adipocytes in primary culture. J Nutr 1996;126:865-870.

30 He YH, He Y, Liao XL, Niu YC, Wang G, Zhao C, Wang L, Tian MJ, Li Y, Sun CH: The calcium-sensing receptor promotes adipocyte differentiation and adipogenesis through PPARgamma pathway. Mol Cell Biochem 2012;361:321-328.

-31 Zhang XH, Huang B, Choi SK, Seo JS: Anti-obesity effect of resveratrol-amplified grape skin extracts on 3T3L1 adipocytes differentiation. Nutr Res Pract 2012;6:286-293.

32 Ho JN, Choi JW, Lim WC, Kim MK, Lee IY, Cho HY: Kefir inhibits 3T3-L1 adipocyte differentiation through down-regulation of adipogenic transcription factor expression. J Sci Food Agric 2013;93:485-490. 
-33 Cariou B, Charbonnel B, Staels B: Thiazolidinediones and PPARgamma agonists: time for a reassessment. Trends Endocrinol Metab 2012;23:205-215.

-34 Zimmermann R, Strauss JG, Haemmerle G, Schoiswohl G, Birner-Gruenberger R, Riederer M, Lass A, Neuberger G, Eisenhaber F, Hermetter A, Zechner R: Fat mobilization in adipose tissue is promoted by adipose triglyceride lipase. Science 2004;306:1383-1386.

-35 Bonen A, Parolin ML, Steinberg GR, Calles-Escandon J, Tandon NN, Glatz JF, Luiken JJ, Heigenhauser GJ, Dyck DJ: Triacylglycerol accumulation in human obesity and type 2 diabetes is associated with increased rates of skeletal muscle fatty acid transport and increased sarcolemmal FAT/CD36. FASEB J 2004;18:1144-1146.

-36 Luiken JJ, Arumugam Y, Dyck DJ, Bell RC, Pelsers MM, Turcotte LP, Tandon NN, Glatz JF, Bonen A: Increased rates of fatty acid uptake and plasmalemmal fatty acid transporters in obese Zucker rats. J Biol Chem 2001;276:40567-40573.

37 Luiken JJ, Arumugam Y, Bell RC, Calles-Escandon J, Tandon NN, Glatz JF, Bonen A: Changes in fatty acid transport and transporters are related to the severity of insulin deficiency. Am J Physiol Endocrinol Metab 2002;283:E612-E621.

-38 Steinberg GR, Dyck DJ, Calles-Escandon J, Tandon NN, Luiken JJ, Glatz JF, Bonen A: Chronic leptin administration decreases fatty acid uptake and fatty acid transporters in rat skeletal muscle. J Biol Chem 2002;277:8854-8860.

39 Bonen A, Luiken JJ, Liu S, Dyck DJ, Kiens B, Kristiansen S, Turcotte LP, Van Der Vusse GJ, Glatz JF: Palmitate transport and fatty acid transporters in red and white muscles. Am J Physiol 1998;275:E471-E478.

$\checkmark 40$ Bonen A, Tandon NN, Glatz JF, Luiken JJ, Heigenhauser GJ: The fatty acid transporter FAT/CD36 is upregulated in subcutaneous and visceral adipose tissues in human obesity and type 2 diabetes. Int J Obes (Lond) 2006;30:877-883.

41 Kozak LP, Kozak UC, Clarke GT: Abnormal brown and white fat development in transgenic mice overexpressing glycerol 3-phosphate dehydrogenase. Genes Dev 1991;5:2256-2264.

42 Prochazka M, Kozak UC, Kozak LP: A glycerol-3-phosphate dehydrogenase null mutant in BALB/cHeA mice. J Biol Chem 1989;264:4679-4683. 